\title{
Experimental Investigation on the Advantages of Dry Machining over Wet Machining during Turning of AISI 1020 Steel
}

\author{
Boki Dugo Bedada ${ }^{1}$, Guteta Kabeta Woyesssa ${ }^{1}$, Moera Gutu Jiru ${ }^{1, *}$, Besufekad Negash \\ Fetene $^{2}$ and Tekle Gemechu ${ }^{3}$
}

\author{
${ }^{1}$ Department of Mechanical Design and Manufacturing Engineering Adama Science and Technology \\ University, Adama, Ethiopia \\ ${ }^{2}$ Department of Mechanical Engineering, Defence University College of Engineering, Bishoftu, Ethiopia \\ ${ }^{3}$ Departiment of Mathematics, Adama Science and Technology University Adama, Ethiopia
}

\begin{abstract}
In this study, the experiment was conducted to investigate the advantage of dry machining over wet machining during turning of AISI 1020 steel using cemented carbide tool on a CNC lathe machine. Surface roughness and cutting temperature were measured by VOGEL surface roughness tester and infrared thermometer respectively. The experiments were conducted based on Taguchi L9 orthogonal array design. Surface roughness, cutting temperature, tool life, and machining cost were analyzed graphically. The average surface roughness and cutting temperature achieved with wet machining was $2.01 \mu \mathrm{m}$ and $26.54^{\circ} \mathrm{C}$, which was $17.41 \%$ and $44.86 \%$ respectively, lower than dry machining. The high cutting temperature in dry turning result in short tool life, which was $41.15 \%$ shorter than wet turning. The machining cost of wet turning was about $56 \%$ greater than the cost of dry turning. The cost of coolant in wet turning is $42.88 \%$ greater than that of the cutting tools. The highest cost was shared by tool cost, which was $81.33 \%$ of the total cost for dry turning, while $70.00 \%$ of the total cost was shared by coolant cost for wet turning. Results revealed that dry turning is more economical than wet turning.
\end{abstract}

Keywords: Dry machining, Wet machining, AISI 1020 Steel, Surface roughness, Machining cost.

\section{INTRODUCTION}

Most metal manufacturing factories demonstrate that metal cutting operations are carried out dry. However, in many other cases, cutting fluid is directed over the tool, to act as a coolant. Metal fabrication industries were compelled to consider dry machining to enforce environmental protection laws for occupational safety and health regulations (Sarikaya et al. 2021; Bagherzadeh and Budak, 2018; Aggarwal et al., 2008). Dry machining is ecologically desirable and is considered a necessity for manufacturing enterprises. Dry machining gives advantages of non-pollution of the environment, reduced disposal and cleaning costs, no danger to health, and it offers machining cost reduction (Ogedengbe et al., 2018; Kumar et al., 2015; Weinert et al. 2014). However, in dry cutting operations, the friction and adhesion between chip and tool tend to be higher, which causes higher temperatures, higher wear rates, and, consequently, shorter tool life (Yildirim et al., 2020; Pay et al., 2017). On the contrary, machining using cutting fluids has the advantage of better part quality, less tool wear, increases the tool life, contributes to a more economical cutting speed, and

\footnotetext{
*Address correspondence to this author at the Department of Mechanical Design and Manufacturing Engineering Adama Science and Technology University, Adama, Ethiopia;

Email: moera.guta@astu.edu.et
}

improves the efficiency of the production systems (Galanis et al., 2008). Moreover, cutting fluids used to prevent the tool, workpiece, and machine from overheating and distorting improve surface finish and clean the chips from the cutting area.

(Dilbag and Rao, 2008) pointed out that dry turning can enhance a good surface finish, but it reduces tool life and cause tool wear problems. (Debnath et al., 2016) concluded that dry machining is applicable for machining steels, steel alloys, and cast irons except for aluminum alloys. Even though, the high friction at a tool-chip interface in dry cutting conditions significantly increases in temperature causes a higher level of abrasion, diffusion, and oxidation. (Azwadi et al., 2017; Akhil et al. 2016) mentioned that by using dry machining, the manufacturing cost of up to $7-17 \%$ can be reduced when compared to cutting fluid. However, in dry machining, a high level of friction between the two surfaces (tool-workpiece and tool-chips), can be brought to a high temperature in the cutting zone. The high temperature at the machining zone will eventually lead to short tool life and inaccurate dimensions of the workpiece (Sharma et al., 2011; O'sullivan et al., 2001; Sreejith et al., 2000). Therefore the disadvantages associated with it should be compensated to pursue dry machining (Bhuiyan et al., 2014]. The region with high temperature is shown as in Figure 1 below. 


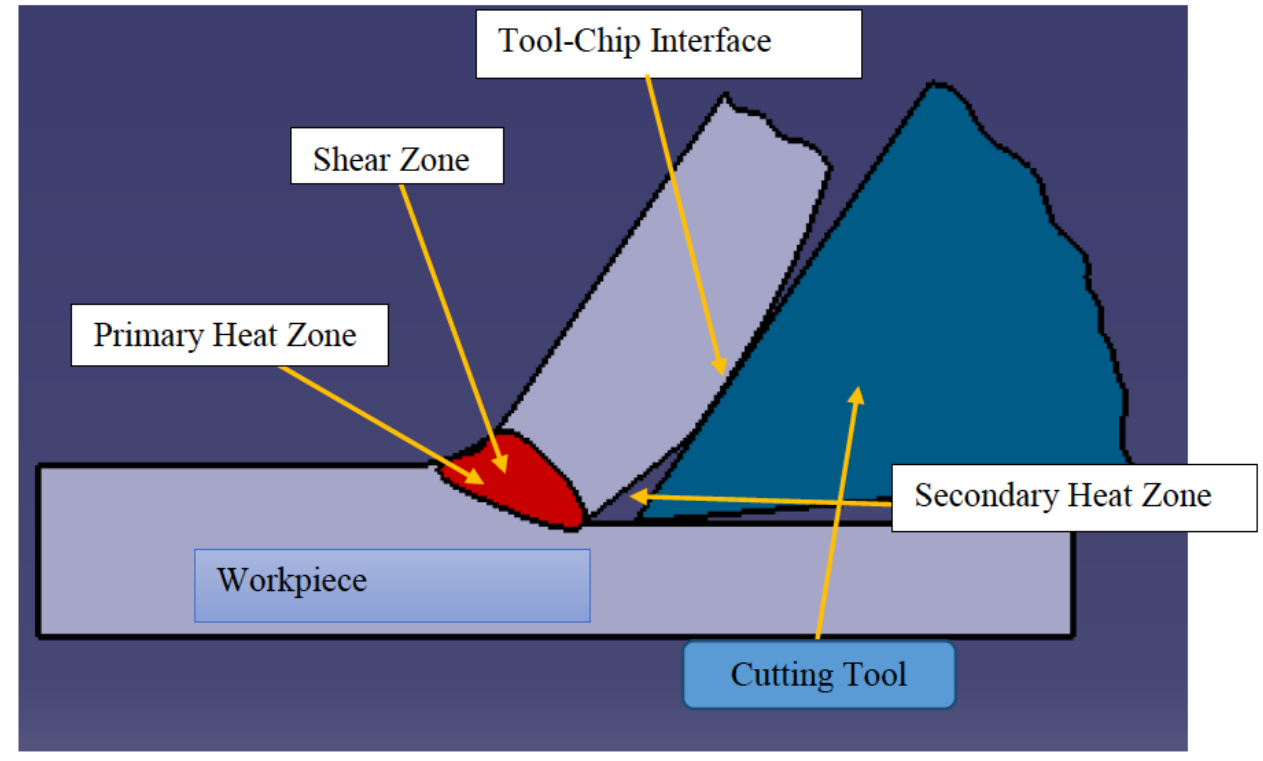

Figure 1: Regions of heat generation in turning.

Wet machining is a machining technique in which a cooling jet is aimed at the active zone for cooling, lubricating, and gets rid of chips produced during machining. It is highly suitable for the grinding and turning process where high temperatures or sparks may occur can be avoided due to the water content of the coolant, which is present in the emulsion used (Anton et al., 2015; Palanisamy et al., 2009; Isik, 2010). During their study on analysis of the cutting fluid, (Adler et al., 2006) found one of the advantages of cutting fluids in machining operation is the ability to reduce heat generated at tool chip interface during machining. The reduction of heat can give a great benefit in the reduction of error surface, where the size of the machined surface irregularities of a surface is produced under ideal conditions. Besides, mechanical energy is used to form the chip to generate heat and high temperatures in the cutting region. (Aggarwal et al., 2008) concluded that the main purpose of using cutting fluids in machining processes is to reduce the cutting temperature.

The study was focused on the experimental investigation on the advantages of dry machining over wet machining during turning of AISI 1020 Steel. Although enormous work available on machining have reported on dry and wet machining process separately, rare work is reported on the dry and wet machining of the same material to investigate advantages of dry machining over wet machining. Therefore in this work, dry and wet turning processes were conducted on a CNC lathe for turning of AISI 1020 steel to investigate the advantage of dry turning over wet turning concerning surface roughness and machining cost. Furthermore, the aim of this work is to overcome the nowadays limitations of the study on dry and wet turning process to investigate advantages of dry machining over wet machining and to determine the machining performance during dry and wet turning of AISI1020 steel.

\section{MATERIALS AND METHODS}

In the present study, AISI 1020 grade steel is used as work material. Its chemical composition is given as in the following Table 1.

Cemented carbide tool insert (CNMG120408) with a chemical composition of $(65 \% \mathrm{~W}, 14 \% \mathrm{Ti}, 9 \%$ Co and $12 \% \mathrm{C}$ ) is used for this experimental study. The tip has a tool angle of $30^{\circ}$ and a nose radius of $1.6 \mathrm{~mm}$. The DMTG CNC lathe machine with CKE 6150 model and

Table 1: Chemical Composition of AISI 1020 Steel Material (wt \%)

\begin{tabular}{|c|c|c|c|c|c|c|c|c|c|c|c|}
\hline C & Si & $M n$ & $\mathbf{P}$ & $S$ & $\mathrm{Cr}$ & Mo & $\mathbf{N i}$ & Al & Co & $\mathrm{Cu}$ & $\mathrm{Fe}$ \\
\hline 0.20 & 0.0046 & 0.386 & 0.018 & 0.02 & 0.025 & 0.0051 & 0.0077 & 0.0757 & 0.0157 & 0.014 & 99.3 \\
\hline
\end{tabular}


Table 2: Characteristics of the Oil used as a Coolant

\begin{tabular}{|c|c|c|c|c|c|c|}
\hline $\begin{array}{c}\text { Kinematic Viscosity } \\
@ \mathbf{2 0} \mathbf{~}^{\circ} \mathbf{C}(\mathbf{C S t})\end{array}$ & $\begin{array}{c}\text { Specific Gravity } \\
\mathbf{Q} 2 \mathbf{0}^{\circ} \mathbf{C}\end{array}$ & $\begin{array}{c}\text { Boiling Point } \\
\left.\mathbf{(}^{\circ} \mathbf{C}\right)\end{array}$ & $\begin{array}{c}\text { Melting Point } \\
\left({ }^{\circ} \mathbf{C}\right)\end{array}$ & $\begin{array}{c}\text { Acid Value } \\
\left(\mathbf{m g K O H g}^{-} \mathbf{1}\right)\end{array}$ & $\begin{array}{c}\text { lodine Value } \\
\left.\mathbf{( m g l g}^{-} \mathbf{1}\right)\end{array}$ & $\begin{array}{c}\text { Saponification Value } \\
\left(\mathbf{m g K O H g}^{-} \mathbf{1}\right)\end{array}$ \\
\hline \hline 84 & 0.911 & 300 & -6 & 0.8 & 80 & 190 \\
\hline
\end{tabular}

power $7 \mathrm{KW}$ with a specification size of $\varnothing 500 \times 1000 \mathrm{~mm}$ was used for this study. Surface roughness was measured by the VOGEL Surface Roughness Tester with the 65711 model. The infrared thermometer was used to measure the cutting temperature.

\subsection{Cutting Fluid Specification Used in Wet Turning}

Vegetable-based oil is used in wet turning. The characteristics of the oil is as in the Table 2;

\subsection{Selection of Process Parameter}

The experiment was conducted by varying the cutting parameters such as spindle speed, feed rate, depth of cut, and the cutting parameters have been split into different level values. Level of cutting parameters were selected depending on knowledge found in the literature, according to the recommendations of tool manufacturer, and manufacturer's handbook recommended for the tested material (Debnath et al., 2016; Tugrul et al., 2007; Isik, 2010; Kagade et al., 2011).

The selected cutting parameters were shown in Table 3.

Table 3: List of Parameters and their Levels

\begin{tabular}{|c|c|c|c|c|}
\hline \multirow{2}{*}{$\begin{array}{c}\text { Cutting } \\
\text { Parameters }\end{array}$} & Designations & \multicolumn{3}{|c|}{ Levels } \\
\cline { 3 - 5 } & $\mathrm{t}$ & $\mathbf{2}$ & $\mathbf{3}$ \\
\hline \hline Depth of Cut (mm) & $\mathrm{f}$ & 60 & 80 & 100 \\
\hline $\begin{array}{c}\text { Feed Rate } \\
\text { (mm/min) }\end{array}$ & $\mathrm{N}$ & 500 & 800 & 1100 \\
\hline $\begin{array}{c}\text { Spindle Speed } \\
\text { (RPM) }\end{array}$ & & & 0.5 & 0.75 \\
\hline
\end{tabular}

\subsection{Design of Experiment}

The experiment was conducted according to $\mathrm{L}_{9}$ orthogonal array which is generated by Minitab-18 software. For each experiment separate tool insert is used.
Table 4: Experimental Layout Using an L9 Orthogonal Array

\begin{tabular}{|c|c|c|c|}
\hline $\begin{array}{c}\text { Exp. } \\
\text { No }\end{array}$ & $\begin{array}{c}\text { Depth of Cut } \\
(\mathbf{m m})\end{array}$ & $\begin{array}{c}\text { Feed rate } \\
(\mathbf{m m} / \mathbf{m i n})\end{array}$ & $\begin{array}{c}\text { Spindle Speed } \\
(\mathbf{r e v} / \mathbf{m i n})\end{array}$ \\
\hline \hline 1 & 0.25 & 60 & 500 \\
\hline 2 & 0.25 & 80 & 800 \\
\hline 3 & 0.25 & 100 & 1100 \\
\hline 4 & 0.5 & 60 & 800 \\
\hline 5 & 0.5 & 80 & 1100 \\
\hline 6 & 0.5 & 100 & 500 \\
\hline 7 & 0.75 & 60 & 1100 \\
\hline 8 & 0.75 & 80 & 500 \\
\hline 9 & 0.75 & 100 & 800 \\
\hline
\end{tabular}

\subsection{Specimen Preparations}

Two AISI 1020 mild steel specimen of $400 \mathrm{~mm}$ in length and $30 \mathrm{~mm}$ in diameter was prepared and it was gone to turning process with $1 \mathrm{~mm}$ depth of cut to remove any irregular parts on the surface for $300 \mathrm{~mm}$ of length. And then nine experiments with length of $30 \mathrm{~mm}$ and $0.75,0.5$ and $0.25 \mathrm{~mm}$ of depth of cut were operated with different turning parameters for experimental study with different cutting parameters which were selected by using orthogonal array. As it was shown in orthogonal array for the first three run of experiment with similar depth of cut, turning was performed on one piece which consists of three specimen as shown in Figure $\mathbf{2}$ below. Similarly for the experiment run with second and third level of depth of cut.

\section{RESULTS AND DISCUSSION}

Figure 2 shows the dry and wet turned specimen. Each piece consists of three specimens. The specimen name start with ' $W$ ' is wet turned specimens while the other that start with ' $D$ ' is dry turned specimens. Each number on the specimen corresponds to the run order in the orthogonal array. 


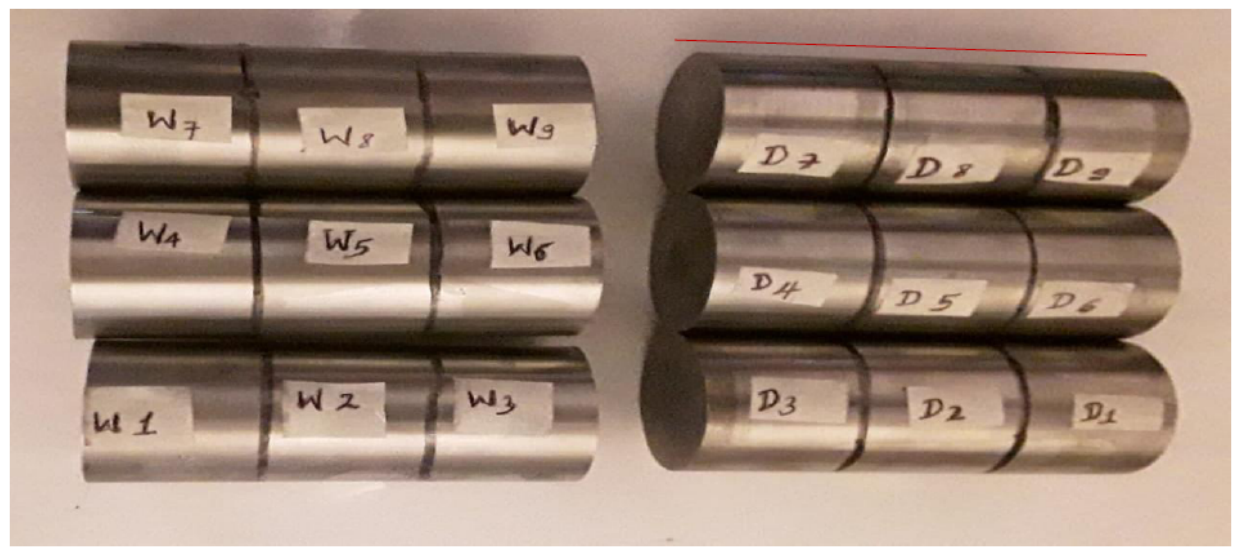

Figure 2: $\quad$ Wet and Dry turned Specimens.

\subsection{Analysis of Surface Roughness}

Tables $\mathbf{5}$ and $\mathbf{6}$ presents the experimental results of surface roughness $(\mathrm{Ra})$ values for each specimen which was measured three times and their average values for dry and wet turning respectively. Each surface roughness $(\mathrm{Ra})$ value is the average of three trial readings.

Surface roughness under dry and wet machining at different conditions as shown in Figure 3. It was clearly shown that the surface roughness produced under wet turning is lower than that produced under dry turning. Considering the average of all roughness results measured under dry and wet turning, the surface roughness achieved with wet machining is $17.41 \%$ lower than dry machining. The previous study by $(\mathrm{Y}$. Kaynak et al., 2014) concluded that the role of wet turning on surface roughness was explained as; wet machining diminishes tool wear compared to dry machining, wet machining helps to preserve the tool geometry for a long time by reducing or eliminating possible built-up-edge (BUE) formation and wet turning prevents a possible distortion of the workpiece due to the high-temperature effect.

The high tool-workpiece interface temperature effect in dry cutting results in the chips attached loosely to the surface being eliminated easily which contributes to the improvement of the surface roughness. The penetration of coolant into the cutting zone reduces friction between the contacting elements and lowers the temperature. Other researchers who obtained similar results stated that the need to cool the cutting zone with cutting fluid was to reduce friction by lubricating the contacting surfaces during machining (Yıldırım et al., 2020; Bagherzadeh and Budak, 2018). It is shown from Figure 3 that the surface roughness was increased with increasing spindle speed while the

Table 5: Experimental Result of Surface Roughness $\mathbf{R}_{\mathrm{a}}$ for Dry Turning

\begin{tabular}{|c|c|c|c|c|c|c|c|}
\hline \multirow{2}{*}{ No } & \multicolumn{3}{|c|}{ Cutting Parameters } & \multicolumn{4}{|c|}{ Surface Roughness, $R_{a}(\mu \mathrm{m})$} \\
\hline & $\mathrm{t}(\mathrm{mm})$ & $f(\mathrm{~mm} / \mathrm{min})$ & N (RPM) & I & II & III & Average \\
\hline 1 & 0.25 & 60 & 500 & 2.19 & 2.25 & 2.22 & 2.2 \\
\hline 2 & 0.25 & 80 & 800 & 1.89 & 1.85 & 1.87 & 1.87 \\
\hline 3 & 0.25 & 100 & 1100 & 2.10 & 2.15 & 2.14 & 2.13 \\
\hline 4 & 0.5 & 60 & 800 & 1.97 & 1.92 & 1.97 & 1.95 \\
\hline 5 & 0.5 & 80 & 1100 & 1.76 & 1.85 & 1.70 & 1.77 \\
\hline 6 & 0.5 & 100 & 500 & 4.06 & 3.91 & 4.00 & 3.99 \\
\hline 7 & 0.75 & 60 & 1100 & 1.68 & 1.82 & 1.78 & 1.76 \\
\hline 8 & 0.75 & 80 & 500 & 3.19 & 3.24 & 3.32 & 3.25 \\
\hline 9 & 0.75 & 100 & 800 & 3.08 & 2.88 & 2.95 & 2.97 \\
\hline
\end{tabular}


Table 6: Experimental Result of Surface Roughness $R_{a}$ for Wet Turning

\begin{tabular}{|c|c|c|c|c|c|c|c|}
\hline \multirow{2}{*}{ No } & \multicolumn{3}{|c|}{ Cutting Parameters } & \multicolumn{4}{|c|}{ Surface Roughness, $R_{a}(\mu m)$} \\
\hline & $t(\mathrm{~mm})$ & $f(\mathrm{~mm} / \mathrm{min})$ & N (RPM) & $\mathbf{I}$ & II & III & Average \\
\hline 1 & 0.25 & 60 & 500 & 2.12 & 1.87 & 1.94 & 1.98 \\
\hline 2 & 0.25 & 80 & 800 & 1.48 & 1.54 & 1.58 & 1.53 \\
\hline 3 & 0.25 & 100 & 1100 & 2.04 & 1.85 & $2 . .01$ & 1.97 \\
\hline 4 & 0.5 & 60 & 800 & 1.65 & 1.26 & 1.91 & 1.61 \\
\hline 5 & 0.5 & 80 & 1100 & 1.36 & 1.32 & 1.50 & 1.39 \\
\hline 6 & 0.5 & 100 & 500 & 3.68 & 3.16 & 2.98 & 3.27 \\
\hline 7 & 0.75 & 60 & 1100 & 1.30 & 1.32 & 1.26 & 1.29 \\
\hline 8 & 0.75 & 80 & 500 & 2.69 & 2.72 & 2.75 & 2.72 \\
\hline 9 & 0.75 & 100 & 800 & 2.19 & 2.42 & 2.35 & 2.32 \\
\hline
\end{tabular}

opposite effect has occurred with increasing feed rate. The results are in line with the literature, and the details of this outcome were discussed in previous studies (Sarikaya and A. Güllü, 2014).

As shown in Figure 3 the surface roughness of dry turning was higher than when the surface roughness of wet turning. The average surface roughness of nine experimental run of wet turning and dry turning were $2.01 \mu \mathrm{m}$ and $2.43 \mu \mathrm{m}$ respectively. The result shows that the average of surface roughness of wet turning was $2.01 \mu \mathrm{m}$ and $26.54^{\circ} \mathrm{C}$, which was $17.41 \%$ lower than the average of surface roughness of dry turning. Maximum and minimum value of surface roughness was obtained at experiment numbers 6 and 7 respectively both for dry and wet turning. This is because of the maximum feed rate and minimum spindle speed at run number 6 and minimum feed and maximum spindle speed at run number 7 .

\subsection{Analysis of Cutting Temperature}

Table 7 shows the experimental result of cutting temperatures as designed according to the Taguchi method.

The comparison cutting temperature for dry and wet turning were shown in Figure 5. The graph shows that the cutting temperature for wet turning was smaller as compared to dry turning. The average of all temperature results saved under dry and wet turning were computed, the result were $48.14^{\circ} \mathrm{C}$ and $26.54^{\circ} \mathrm{C}$ respectively. The result shows that the average cutting temperature of wet turning is lower by $44.86 \%$ than the average cutting temperature of dry turning. The cutting fluid penetrates the cutting zone to absorb the heat generated during machining. This cools the workpiece and tool surface. Moreover, the results imply that applying cutting fluids to the cutting zone reducing friction by lubricating the contacting surfaces which

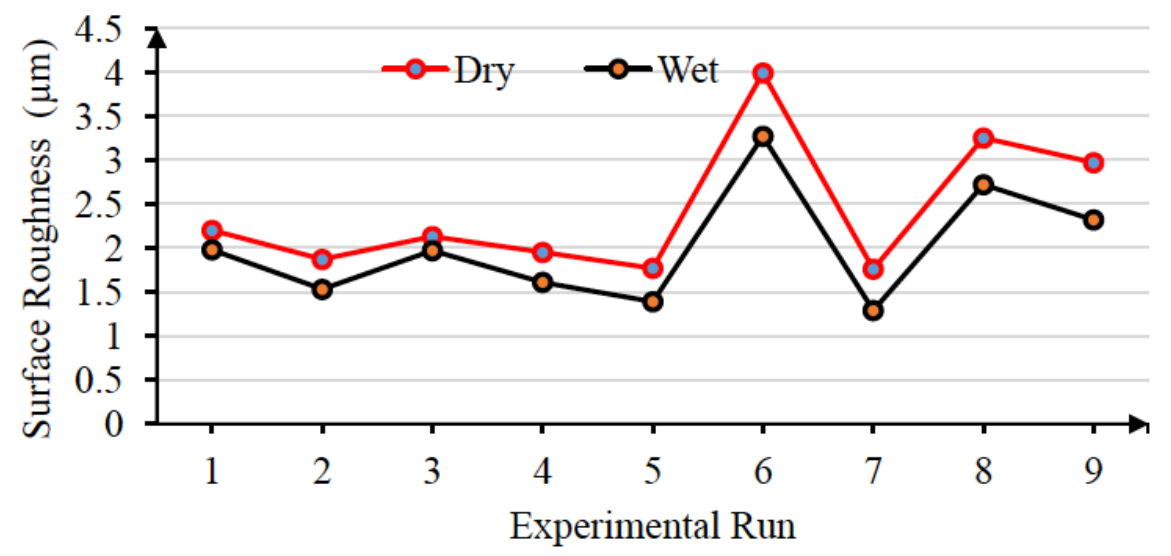

Figure 3: Surface roughness for each experimental run. 
Table7: Experimental Plan and Result for Cutting Temperature

\begin{tabular}{|c|c|c|c|c|c|}
\hline \multirow{2}{*}{ Exp't No } & \multirow{2}{*}{ Depth of Cut (mm) } & \multirow{2}{*}{ Feed Rate $(\mathrm{mm} / \mathrm{min})$} & \multirow{2}{*}{ Spindle Speed (RPM) } & \multicolumn{2}{|c|}{ Temperature $\left({ }^{\circ} \mathrm{C}\right)$} \\
\hline & & & & Dry & Wet \\
\hline 1 & 0.25 & 60 & 500 & 38.2 & 24.2 \\
\hline 2 & 0.25 & 80 & 800 & 43.4 & 25.8 \\
\hline 3 & 0.25 & 100 & 1100 & 53.8 & 28.3 \\
\hline 4 & 0.5 & 60 & 800 & 45.0 & 26.4 \\
\hline 5 & 0.5 & 80 & 1100 & 58.3 & 27.0 \\
\hline 6 & 0.5 & 100 & 500 & 41.8 & 25.6 \\
\hline 7 & 0.75 & 60 & 1100 & 59.2 & 28.1 \\
\hline 8 & 0.75 & 80 & 500 & 44.1 & 26.4 \\
\hline 9 & 0.75 & 100 & 800 & 49.5 & 27.1 \\
\hline
\end{tabular}

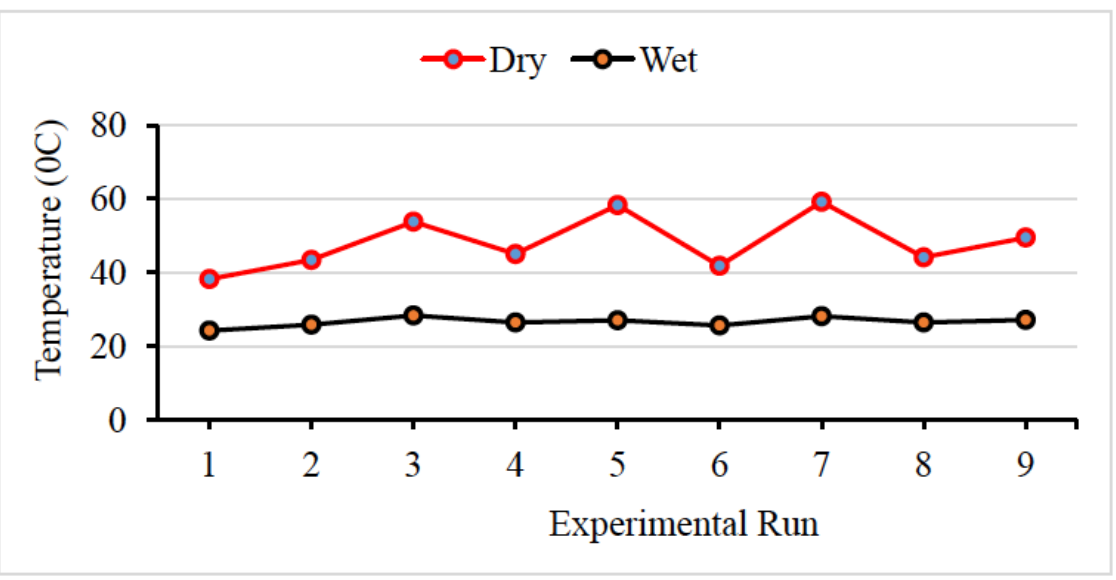

Figure 4: Cutting Temperature value for each experimental run.

tends to reduce cutting temperature. It is clearly shown from Figure 4 that the cutting temperature increased with increasing spindle speed.

\subsection{Analysis of Tool Life}

The tool life for dry turning and wet turning was calculated using Taylor tool life equation.

$V T^{n} f^{a} t^{b}=C$

Where, $n, a$, and $b$ are Taylor's tool life exponent and $C$ is constant. The values of ' $n$ ' and ' $C$ ' depend mainly upon the tool work materials and the value of ' $a$ ' and ' $b$ ' depends on tool-work material and the cutting environment (cutting fluid application). The values of the constants are available in Machining Data Handbooks and can be evaluated from machining tests. In practice, typical values for cemented carbide tools for machining steel (low carbon steel) as workpieces are given in Table 8 (Groover, 2013; Rao et al., 2014; Nilesh et al., 2016; Kawthar 2016).

Table 8: Taylor Tool Life Equation Constant Values

\begin{tabular}{|c|c|c|c|c|}
\hline \multirow{2}{*}{$\begin{array}{c}\text { Cutting } \\
\text { Conditions }\end{array}$} & \multicolumn{4}{|c|}{ Taylor Tool Life Equation Constants } \\
\cline { 2 - 5 } & $\boldsymbol{C}$ & $\boldsymbol{n}$ & $\boldsymbol{a}$ & $\boldsymbol{b}$ \\
\hline \hline Dry Turning & 500 & 0.25 & 0.30 & 0.15 \\
\hline Wet Turning & 500 & 0.25 & 0.45 & 0.2 \\
\hline
\end{tabular}

Tool life for dry and wet turning were calculated for each run of an experiment as in Table 9. As shown the longer tool life was obtained when all the cutting parameters are at their minimum level both in dry and wet turning conditions. At the first experimental run, all parameters are in their minimum level (i.e. $0.25 \mathrm{~mm}$ depth of cut, $60 \mathrm{~mm} / \mathrm{min}$ feed rate, and 500RPM spindle 
Table 9: Tool Life Result for Dry Turning

\begin{tabular}{|c|c|c|c|c|c|}
\hline \multirow{2}{*}{$S / n$} & \multicolumn{3}{|c|}{ Cutting Parameters } & \multicolumn{2}{|c|}{ Tool Life (min) } \\
\hline & Depth of Cut (mm) & Feed Rate $(\mathrm{mm} / \mathrm{min})$ & Spindle Speed (RPM) & Dry Turning & Wet Turning \\
\hline 1 & 0.25 & 60 & 500 & 14.22 & 43.60 \\
\hline 2 & 0.25 & 80 & 800 & 8.09 & 12.33 \\
\hline 3 & 0.25 & 100 & 1100 & 6.44 & 7.30 \\
\hline 4 & 0.5 & 60 & 800 & 7.95 & 10.95 \\
\hline 5 & 0.5 & 80 & 1100 & 6.31 & 6.73 \\
\hline 6 & 0.5 & 100 & 500 & 9.68 & 17.01 \\
\hline 7 & 0.75 & 60 & 1100 & 6.40 & 6.76 \\
\hline 8 & 0.75 & 80 & 500 & 9.76 & 16.35 \\
\hline 9 & 0.75 & 100 & 800 & 6.68 & 7.33 \\
\hline
\end{tabular}

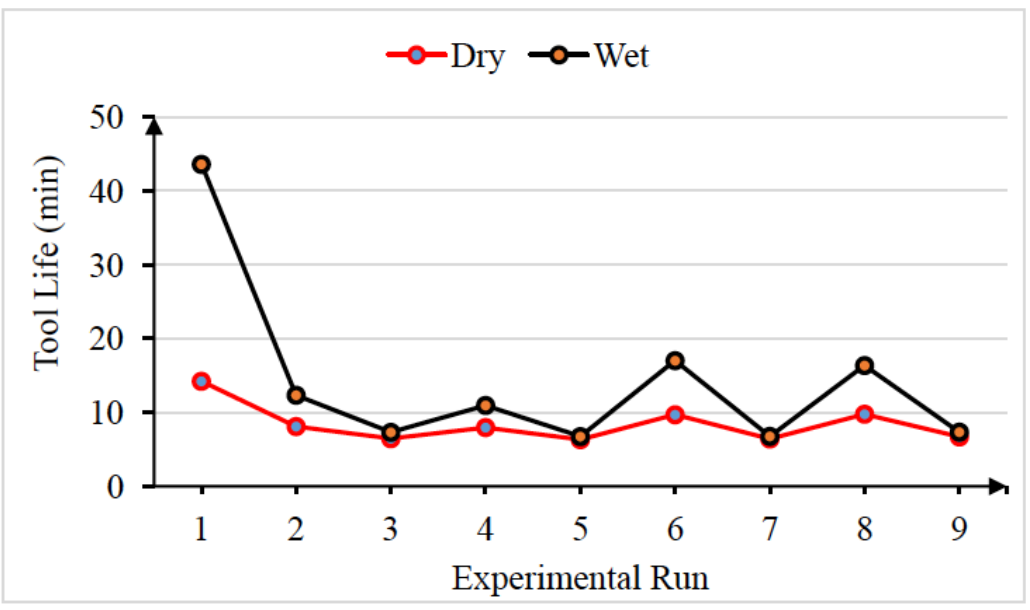

Figure 5: Tool Life for each Experimental Run.

speed) and the maximum tool life of $14.22 \mathrm{~min}$ in dry turning and $43.60 \mathrm{~min}$ in wet turning were obtained.

The comparison of tool life for dry and wet turning as shown in Figure 5. It was shown on graph that the tool life for dry turning reduced as compared wet turning. It is determined that the tool life at wet turning is higher than at dry turning. Maximum tool life was obtained at minimum spindle speed $(500 \mathrm{rpm})$ both for dry and wet turning. As it was explained previously the increase in spindle speed tends to increase the cutting temperature which negatively affects the tool life. Therefore it was concluded from the result that increasing spindle speed tends to increase the cutting temperature which affects the tool life negatively.

\subsection{Analysis Machining Cost}

Achieving an economic machining process is important for metal fabrication industries. The total machining cost $\left(\mathrm{C}_{T}\right)$ comprises energy consumption cost $\left(\mathrm{C}_{e}\right)$, overhead cost $\left(\mathrm{C}_{o}\right)$, cutting tool cost $\left(\mathrm{C}_{t}\right)$, and coolant cost $\left(\mathrm{C}_{c}\right)$ which is described in the following equation.

$C_{T}=C_{e}+C_{o}+C_{t}+C_{c}$

\subsubsection{Analysis of Energy Consumption Cost $\left(C_{\mathrm{e}}\right)$}

Machine tools utilized in the manufacturing industry are responsible for consuming a significant portion of the total energy supplied worldwide. Due to the high unit energy price, energy consumption throughout production is an important factor that determines the total cost of the final product. The lowering in energy consumption enables companies to reduce machining costs. Therefore, analysis of the energy demands of the machine tools at different machining parameters and environments is very important. The electricity energy consumption cost by the machine is dependent 
upon machining time, the machine motor power, and unit energy cost. $\mathrm{Ce}$ can be described by the following relation:

$C_{e}=C_{c u t}+C_{\text {ncut }}$

Ce $=\frac{\text { Unit Energy Cost }}{\eta * 60 * 1000} * t_{m} *($ Cutting Power + Standyby Power $)$

Where $C_{c u t}=$ cutting energy cost, $C_{n c u t}=$ machine standby cost.

While the machining time $t_{m \text {; }}$

$t_{m}=\frac{\text { Length of Cut }+ \text { Machining Allowance }}{\text { Feed Rate } * \text { RPM }}$

As indicated in above equation the electricity consumption cost by the machine tool is dependent upon machining time for which machine tool is used, spindle motor power and unit energy cost. Machining time was calculated using Equation (5) and the result is shown in Table 10. The length of the cut was $30 \mathrm{~mm}$ for each experimental run with $1 \mathrm{~mm}$ allowance. Spindle motor power for DMTG CNC lathe machine with CKE 6150 model is $7 \mathrm{KW}$, coolant pump power is $240 \mathrm{~W}$ and standby power is $2 \mathrm{KW}$ which is constant. The world average price for electric energy consumption is $0.139 \$ / \mathrm{KWh}$ for household users and $0.126 \$ / \mathrm{KWh}$ for business users. The DMTG CNC lathe machine has $85 \%$ efficiency (Gajrani et al, 2017). The energy consumption cost was obtained both for dry and wet turning using Equation (3) and summarized as the following Table 10.

As it was clearly shown in Table $\mathbf{1 0}$ and Figure $\mathbf{6}$ the energy consumption cost for wet turning environment

Table 10: Energy Consumption Cost

\begin{tabular}{|c|c|c|c|c|c|c|}
\hline \multirow{2}{*}{$\mathrm{s} / \mathrm{n}$} & \multicolumn{3}{|c|}{ Cutting Parameters } & \multirow{2}{*}{$\begin{array}{c}\text { Machining Time } \\
t_{m}(\min )\end{array}$} & \multicolumn{2}{|c|}{ Energy Consumption Cost } \\
\hline & $\mathbf{t}(\mathbf{m m})$ & $f(m m / m i n)$ & N (RPM) & & Dry, $C_{e}(\$)$ & Wet, $C_{e}(\$)$ \\
\hline 1 & 0.25 & 60 & 500 & 0.5167 & 0.0115 & 0.0118 \\
\hline 2 & 0.25 & 80 & 800 & 0.3875 & 0.0086 & 0.0088 \\
\hline 3 & 0.25 & 100 & 1100 & 0.31 & 0.0069 & 0.0071 \\
\hline 4 & 0.5 & 60 & 800 & 0.5167 & 0.0115 & 0.0118 \\
\hline 5 & 0.5 & 80 & 1100 & 0.3875 & 0.0086 & 0.0088 \\
\hline 6 & 0.5 & 100 & 500 & 0.31 & 0.0069 & 0.0071 \\
\hline 7 & 0.75 & 60 & 1100 & 0.5167 & 0.0115 & 0.0118 \\
\hline 8 & 0.75 & 80 & 500 & 0.3875 & 0.0086 & 0.0088 \\
\hline 9 & 0.75 & 100 & 800 & 0.31 & 0.0069 & 0.0071 \\
\hline
\end{tabular}

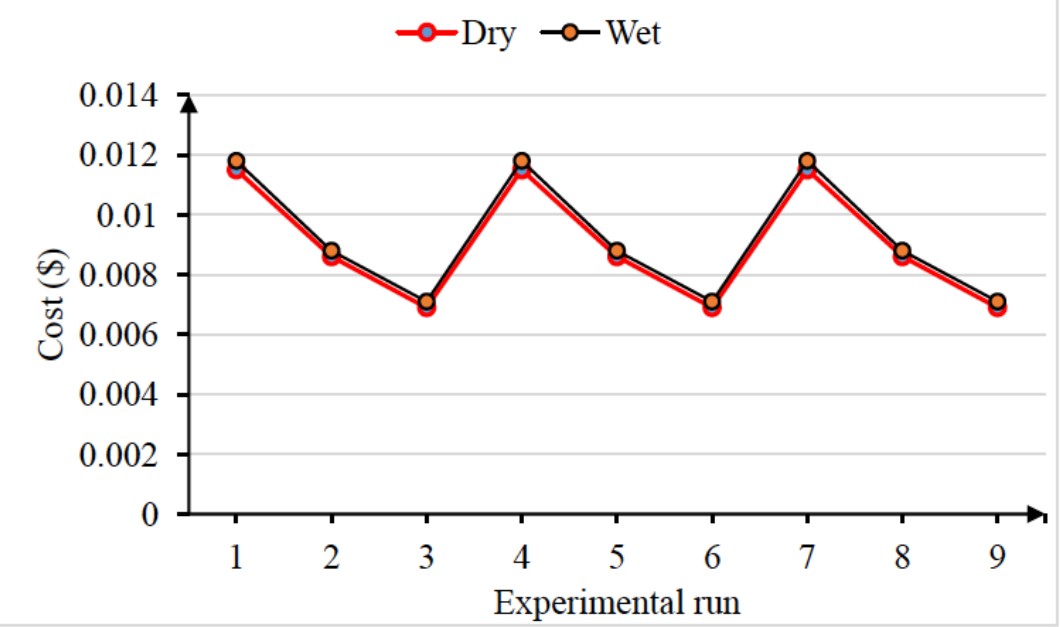

Figure 6: Energy Consumption Cost. 
was greater than that of a dry turning environment because wet turning needs additional power for delivering cutting fluids by coolant pump. The average electrical energy consumption cost for wet turning was about $3 \%$ greater than that of dry turning. At experimental run numbers 1,4 and 7 the energy consumption cost was high. This is due to low value of feed rate which causes high machining time enfulenced a high consumption of electric power.

\subsubsection{Analysis Overhead Cost ( $\left.C_{0}\right)$}

The overhead cost of machining consisted of operator cost $\left(C_{o p}\right)$, cost of lighting and $\operatorname{HVAC}\left(C_{L}\right)$, and machine depreciation cost $\left(C_{m}\right)$ which is given as the following equation:

$C_{o}=C_{o p}+C_{L}+C_{m}$

Where operator cost is the operating cost during the machining and given as follows;

$C_{o p}=$ Operator Labor Rate $* t_{m} *$ Number of workers

Similarly, the cost of lighting;

$C_{L}=($ Cost of Lighting and HVAC $) *$ Unit Energy Cost $*\left({ }_{m} / 60\right)$

The cost of machine depreciation is determined as follows:

$C_{m}=\frac{(\text { Initial Cost-Salvage Value }) * \text { Machining Time }}{\text { Useful Life }}$
Operator cost was calculated by using Equation (6) and operator labor rate $6.57 \$ / \mathrm{hr}$ and 1 operator. Cost of lighting and HVAC was also calculated using Equation (7). The machine cost was calculated by using an initial cost of DMTG CNC lathe machine of CKE 6150 model $20,000 \$$, depreciation value of $1200 \$$ /year, 270 annual working days and the service life of the machine was 5 years (Munish et al., 2021).

The result of the overhead cost was calculated and summarized as in Table 11. In a similar manner to energy consumption cost, the overhead cost was also highly dependent on the feed rate which determines the machining time. As shown in Figure 7 overhead cost was high at low feed rate. Accordingly, it can be deduced from Figure $\mathbf{1 1}$ that the share of the overhead cost in the total cost per unit part is $13.47 \%$ and $6.00 \%$ for dry and wet turning respectively.

\subsubsection{Analysis of Tool Cost $\left(C_{t}\right)$}

During the mass production of components by machining, tool cost takes a substantial part of the total machining cost. To minimize this several measures such as reducing cutting parameters and using coolant fluid are taken as a solution. When the cutting tool insert reaches $0.3 \mathrm{~mm}$ wear value (VBmax $=0.3 \mathrm{~mm}$ ), it can be reground and can be sold at a lower price. Therefore, the net cutting tool inserts cost is:

$$
C_{t}=\frac{\text { Insert Price-Resale Price }}{\text { Tool Life }} * t_{m}
$$

Tool cost depends on initial insert price, resale price after its wear and life of the tool. Unit insert for cemented carbide insert price is $14 \$$ and its resale price is $6 \$$. Tool life for dry and wet turning was taken

Table 11: Overhead Cost

\begin{tabular}{|c|c|c|c|c|c|}
\hline $\mathbf{s} / \mathbf{n}$ & $\begin{array}{c}\mathbf{t}_{\mathbf{m}} \\
(\mathbf{m i n})\end{array}$ & $\begin{array}{c}\text { Operator Cost } \\
\mathbf{( \$ )}\end{array}$ & $\begin{array}{c}\text { Lighting and HVAC cost } \\
\mathbf{( \$ )}\end{array}$ & $\begin{array}{c}\text { Machine Depreciation Cost } \\
\mathbf{( \$ )}\end{array}$ & $\begin{array}{c}\text { Total Overhead Cost } \\
\mathbf{( \$ )}\end{array}$ \\
\hline \hline 1 & 0.5167 & 0.1315 & 0.0246 & 0.0048 & 0.1610 \\
\hline 2 & 0.3875 & 0.0986 & 0.0185 & 0.0036 & 0.1207 \\
\hline 3 & 0.31 & 0.0789 & 0.0148 & 0.0029 & 0.0966 \\
\hline 4 & 0.5167 & 0.1315 & 0.0246 & 0.0048 & 0.1610 \\
\hline 5 & 0.3875 & 0.0986 & 0.0185 & 0.0036 & 0.1207 \\
\hline 6 & 0.31 & 0.0789 & 0.0148 & 0.0029 & 0.0966 \\
\hline 7 & 0.5167 & 0.1315 & 0.0246 & 0.0048 & 0.1610 \\
\hline 8 & 0.3875 & 0.0986 & 0.0185 & 0.0036 & 0.1207 \\
\hline 9 & 0.31 & 0.0789 & 0.0148 & 0.0029 & 0.0966 \\
\hline
\end{tabular}




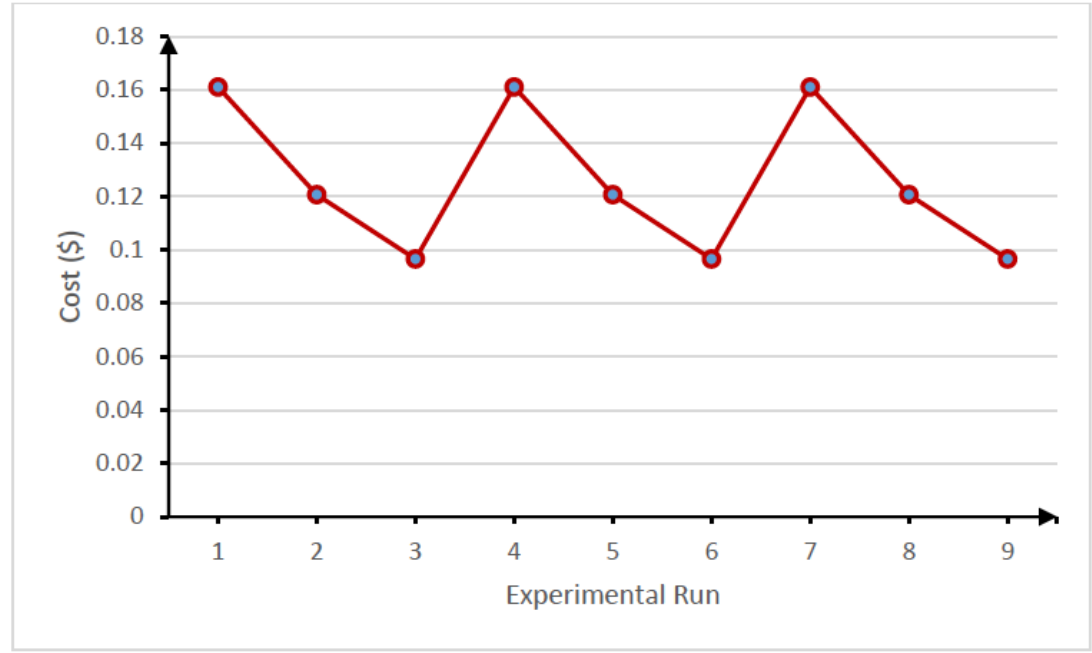

Figure 7: Overhead Cost.

Table 12: Tool Cost

\begin{tabular}{|c|c|c|c|c|c|}
\hline $\mathbf{s} / \mathbf{n}$ & $\begin{array}{c}\mathbf{t}_{\mathbf{m}} \\
(\mathbf{m i n})\end{array}$ & $\begin{array}{c}\text { Dry Turning Tool Life } \\
(\mathbf{m i n})\end{array}$ & $\begin{array}{c}\text { Wet Turning Tool Life } \\
(\mathbf{m i n})\end{array}$ & $\begin{array}{c}\text { Dry Turning Tool Cost } \\
(\mathbf{\$})\end{array}$ & $\begin{array}{c}\text { Wet Turning Tool Cost } \\
\mathbf{( \$ )}\end{array}$ \\
\hline \hline 1 & 0.5167 & 14.22 & 43.60 & 0.291 & 0.095 \\
\hline 2 & 0.3875 & 8.09 & 12.33 & 0.383 & 0.251 \\
\hline 3 & 0.31 & 6.44 & 7.30 & 0.385 & 0.340 \\
\hline 4 & 0.5167 & 7.95 & 10.95 & 0.520 & 0.378 \\
\hline 5 & 0.3875 & 6.31 & 6.73 & 0.491 & 0.461 \\
\hline 6 & 0.31 & 9.68 & 17.01 & 0.256 & 0.146 \\
\hline 7 & 0.5167 & 6.40 & 6.76 & 0.646 & 0.611 \\
\hline 8 & 0.3875 & 9.76 & 16.35 & 0.318 & 0.190 \\
\hline 9 & 0.31 & 6.68 & 7.33 & 0.371 & 0.338 \\
\hline
\end{tabular}

from Table 9. The result of tool cost was calculated using equation (10) and summarized as in Table 13. From the result obtained, the value of tool cost in dry turning was greater than that of wet turning. This is due to the shorter tool life in dry turning. Figure $\mathbf{1 1}$ illustrates the proportion of tool cost in total machining cost. According to this, cutting tool costs account for $81.33 \%$ and $27.60 \%$ of total cost in machining under dry and wet turning conditions respectively. As can be seen, tool cost has the second-largest share after coolant cost in wet turning and it has the largest cost in dry turning condition.

\subsubsection{Analysis of Coolant Cost $\left(C_{c}\right)$}

In addition to energy consumption cost, overhead cost and cutting tool cost wet turning has coolant cost. It is the cost of a specific volume of coolant or cutting fluid. In machining operations, coolant cost is responsible for $15-17 \%$ of the final part cost (Sidik et al., 2017). It has been noted that costs associated with cutting fluids in such operations can be higher than the

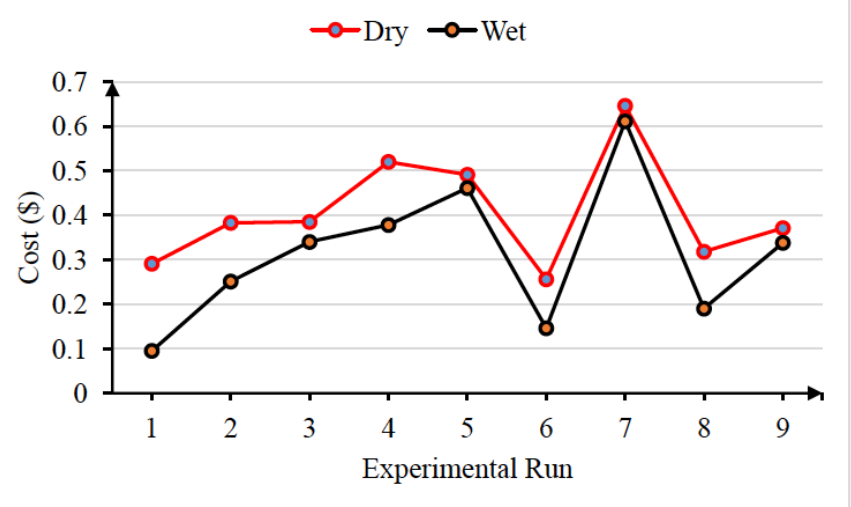

Figure 8: Tool Cost. 
costs of cutting tools (Gajrani, et al., 2017). The cost of lubricant is dependent upon the cost per liter, flow rate, and machining time. Coolant cost is calculated as;

$C_{c}=$ Coolant Cost $*$ Flow Rate $* t_{m}$

Water-soluble oil used in wet turning has a proportion of 1:20 oil to water ratio. The flow rate of the coolant was $3.52 \mathrm{~L} / \mathrm{min}$. the cost of water-soluble oil was $10 \$ / L$. In this study cost of cutting fluid was obtained by using equation (11) and the result was shown as in Table 13. Figure 11 exhibits that the cooling cost has a share of $0 \%$ and $70.00 \%$ within the total cost for dry turning and wet turning, respectively. In an operation using coolant in wet turning is the reason for the higher share of coolant costs in the total cost and it is undoubtedly due to its higher consumption per unit time.

Figure 9 shows the coolant cost for each experimental run. As it is indicated coolant cost is higher in experimental run numbers 1,4 and 7 . This is due to the low feed rate which result in a longer machining time. This longer machining time makes the amount of coolant consumed higher.

\subsubsection{Total Machining Cost}

Total machining cost is the sum of energy consumption cost, overhead cost, tool cost and coolant cost. The total machining cost for dry and wet turning was shown in Table 14. Figure 10 demonstrates the total machining cost for each experimental for different machining environments (i.e. dry turning and wet
Table 13: The Result of Coolant Cost

\begin{tabular}{|c|c|c|c|}
\hline \multirow{2}{*}{$\mathbf{s} / \mathbf{n}$} & Machining Time & \multicolumn{2}{|c|}{ Coolant Cost (\$) } \\
\cline { 2 - 4 } & $\mathbf{t}_{\boldsymbol{m}}$ (min) & Dry & Wet \\
\hline \hline 1 & 0.516667 & 0 & 0.909333 \\
\hline 2 & 0.3875 & 0 & 0.682 \\
\hline 3 & 0.31 & 0 & 0.5456 \\
\hline 4 & 0.516667 & 0 & 0.909333 \\
\hline 5 & 0.3875 & 0 & 0.682 \\
\hline 6 & 0.31 & 0 & 0.5456 \\
\hline 7 & 0.516667 & 0 & 0.909333 \\
\hline 8 & 0.3875 & 0 & 0.682 \\
\hline 9 & 0.31 & 0 & 0.5456 \\
\hline
\end{tabular}

turning). The total machining cost is lower for dry turning as it has been observed in all experimental run. Taking the total average sum of all costs for all experimental run, the cost of wet turning was about $56 \%$ greater than the cost of dry turning. This is because as it was explained that the cost of cutting fluid is greater than that of the cost of the cutting tool which is not present in dry turning. The cost of coolant in wet turning is $42.88 \%$ greater than that of the cutting tool.

Figure 11 (a) and (b) shows the percentage cost sharing of the machining cost in a dry and wet turning environment. As clearly shown in the chart the highest cost was shared by tool cost, which was $81.33 \%$ of the total cost, for dry turning. While $70.00 \%$ of the total cost

Table 14: The Total Cost for Dry and Wet Turning

\begin{tabular}{|c|c|c|c|c|c|c|c|c|c|}
\hline \multirow{3}{*}{$s / n$} & \multicolumn{9}{|c|}{ Cost (\$) } \\
\hline & \multicolumn{2}{|c|}{ Energy } & \multirow{2}{*}{$\begin{array}{l}\text { Overhead } \\
\text { Dry=Wet }\end{array}$} & \multicolumn{2}{|c|}{ Tool } & \multicolumn{2}{|c|}{ Coolant } & \multicolumn{2}{|c|}{ Total } \\
\hline & Dry & Wet & & Dry & Wet & Dry & Wet & Dry & Wet \\
\hline 1 & 0.0332 & 0.0497 & 0.0860 & 0.291 & 0.0948 & 0 & 0.9093 & 0.4100 & 1.1399 \\
\hline 3 & 0.0199 & 0.0298 & 0.0516 & 0.3850 & 0.3397 & 0 & 0.546 & 0.4565 & 0.9668 \\
\hline 4 & 0.0332 & 0.0497 & 0.0860 & 0.5199 & 0.377 & 0 & 0.9093 & 0.6391 & 1.4227 \\
\hline 5 & 0.0249 & 0.0373 & 0.0645 & 0.4915 & 0.4608 & 0 & 0.682 & 0.5809 & 1.2447 \\
\hline 6 & 0.0199 & 0.0298 & 0.0516 & 0.2561 & 0.1458 & 0 & 0.546 & 0.3276 & 0.7728 \\
\hline
\end{tabular}




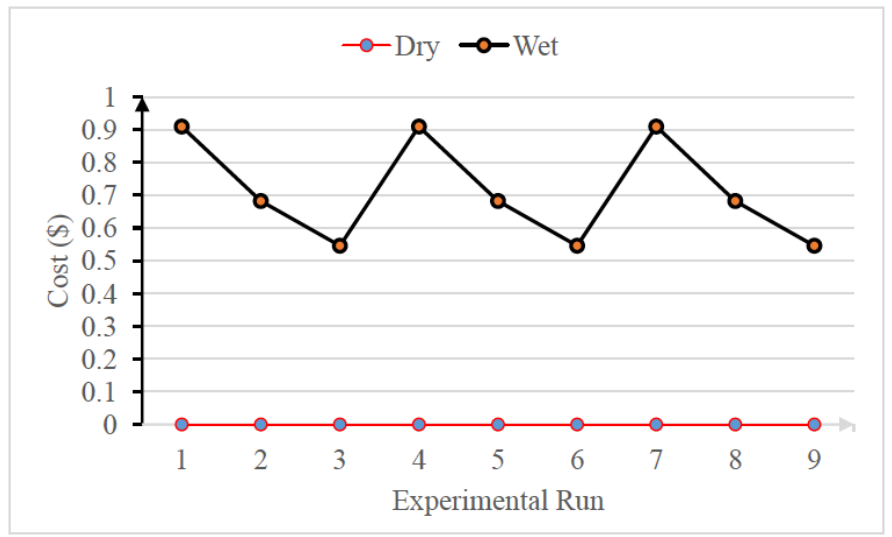

Figure 9: Coolant Cost.

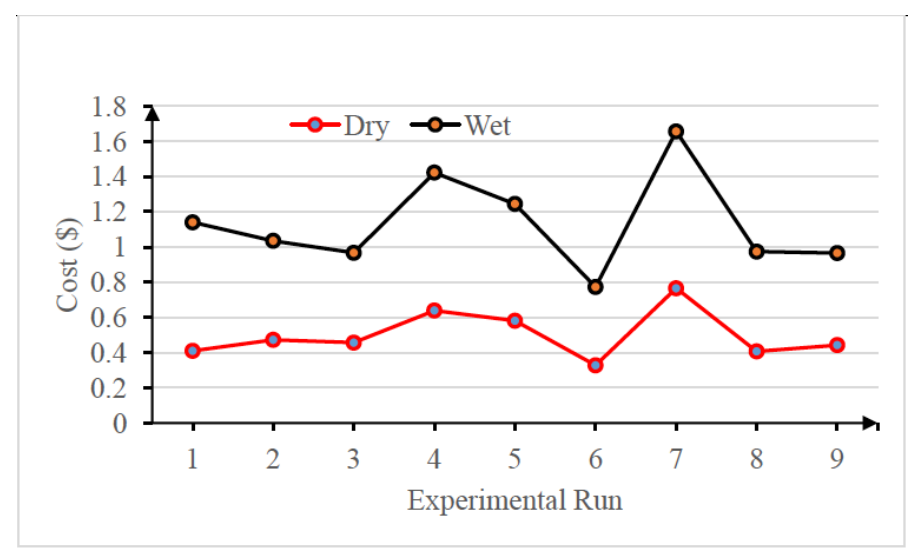

Figure 10: Total machining cost for different experimental runs.

was shared by coolant cost for wet turning.

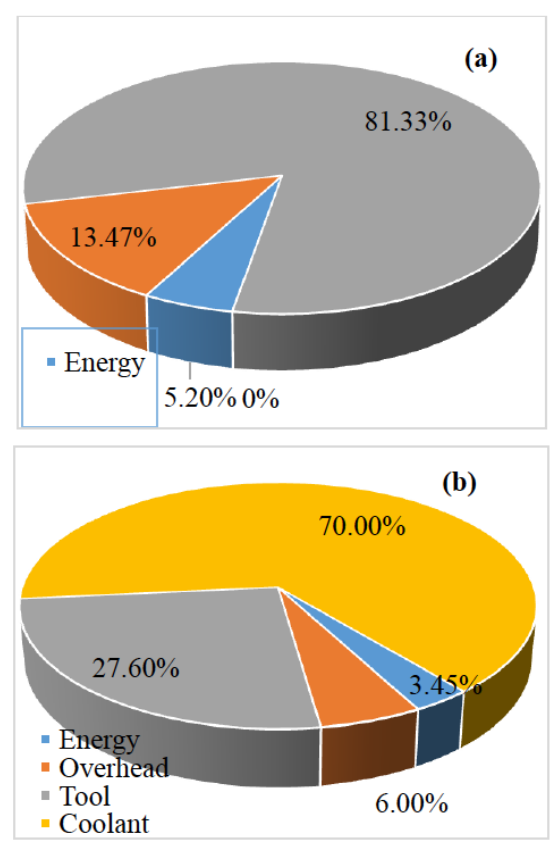

Figure 11: Cost sharing under (a). Dry and (b). Wet turning environment.

\section{CONCLUSION}

This paper explores the experimental investigation on the advantage of dry machining over wet machining during turning of AISI 1020 steel on CNC lathe machine using cemented carbide cutting tool.

- Surface roughness, cutting temperature, tool life, and machining cost were analyzed. The average surface roughness achieved with wet machining was $17.41 \%$ lower than dry machining. The high cutting temperature in dry turning results in short tool life. However, the cost of wet turning was about $56 \%$ greater than the cost of dry turning. This was due to the higher cost of coolant in wet turning which is $42.88 \%$ greater than that of a cutting tool.

- The highest cost was shared by tool cost, which was $81.33 \%$ of the total cost for dry turning, while $70.00 \%$ of the total cost was shared by coolant cost for wet turning.

- $\quad$ Results revealed that even though it shows a little difference in surface roughness and tool life 
is shorter in dry turning since coolant cost was by far greater than tool cost, dry turning is more economical.

\section{REFERENCES}

[1] Munish Kumar Gupta, Qinghua Song, Zhanqiang Liu, Murat Sarikaya, Muhammad Jamil, Mozammel Mia, Vinod Kushvaha, Anil Kumar, Singla, Zhixiong Li, 2021. Ecological, economical and technological perspectives based sustainability assessment in hybrid-cooling assisted machining of Ti-6Al-4 $\mathrm{V}$ alloy, Sustainable Materials and Technologies, Vol. 26, pp. 1-13.

https://doi.org/10.1016/j.susmat.2020.e00218

[2] Ç.V. Yıldırım, T. Kıvak, M. Sarıkaya, and Ş. Şirin, 2020. Evaluation of tool wear, surface roughness/topography and chip morphology when machining of Ni-based alloy 625 under MQL, cryogenic cooling and Cryo MQL, Journal of Material Research and Technology, Vol. 9, Issue 2, pp. 2079-2092.

https://doi.org/10.1016/j.jmrt.2019.12.069

[3] A. Bagherzadeh and E. Budak, 2018. Investigation of machinability in turning of difficult-to-cut materials using a new cryogenic cooling approach, Tribology International, Vol. 119 , pp. 510-520.

https://doi.org/10.1016/j.triboint.2017.11.033

[4] Ogedengbe T.S., Abdulkareem S., and Aweda J.O., 2018. Effect of coolant temperature on machining characteristics of high carbon steel, Covenant Journal of Engineering Technology, Vol. $\quad 1, \quad$ pp. 73-86. https://www.researchgate.net/publication/322833036

[5] N.A.C. Sidik, S. Samion, J. Ghaderian, M.N.A.W.M. Yazid, 2017. Recent progress on the application of nanofluids in minimum quantity lubrication machining: a review, International Journal of Heat and Mass Transfer, Vol. 108, pp. 79-89.

https://doi.org/10.1016/j.ijheatmasstransfer.2016.11.105

[6] Pay Jun Liew, Ainusyafiqah Shaaroni, Nor Azwadi Che Sidik, Jiwang Yan, 2017. An overview of current status of cutting fluids and cooling techniques of turning hard steel, International Journal of Heat and Mass Transfer, Vol. 114, pp. 380-394.

https://doi.org/10.1016/j.ijheatmasstransfer.2017.06.077

[7] K.K. Gajrani, D. Ram and M. Ravi Sankar, 2017. Biodegradation and hard machining performance comparison of eco-friendly cutting fluid and mineral oil using flood cooling and minimum quantity cutting fluid techniques, Journal Cleaner Production, Vol. 165, pp. 1420-1435 https://doi.org/10.1016/j.jclepro.2017.07.217

[8] Nilesh C. Ghuge1, Dr.Ashish M. Mahalle, 2016. Influence of cutting fluid on tool wear and tool life during turning, International Journal of Modern Trend in Engineering and Research, Vol. 3, Issue 10, pp. 23-27. https://doi.org/10.21884/IJMTER.2016.3078.9LPXS

[9] Akhil CS, Ananthavishnu MH, Akhil CK, Afeez PM, and Akhilesh R, Rahul Rajan, 2016.

[10] Measurement of Cutting Temperature during Machining, IOSR Journal of Mechanical and Civil Engineering, Vol. 13, Issue 2 Ver. I, pp. 102-116.

[11] Kawthar Y. AL-Dulaimi 1, Haydar Al-Ethari, and Bogdan Warcholinski, 2016. Taguchi method to optimize machining conditions affecting cemented carbide tool's wear life in turning AISI 1020 steel, Al-Qadisiyah Journal for Engineering Sciences, Vol. 9, Issue 2, pp. 267-278. https://www.researchgate.net/publication/309993825

[12] S. Debnath, MM. Reddy, QS. Yi, 2016. Influence of cutting fluid conditions and cutting parameters on surface roughness and tool wear in turning process using Taguchi method,
Measurement, Vol. 78 pp.111-119.

https://doi.org/10.1016/j.measurement.2015.09.011

[13] Pradeep Kumar M., Amarnath, K., Kumar M.S, 2015. A review on heat generation in metal cutting," International Journal of Engineering, Science and Technology, Vol. 5, Issue 4, pp. 193-197.

[14] S. Dilbag, P. Rao, 2015. Performance improvement of hard turning with solid lubricants, International Journal of Advanced Manufacturing Technology, Vol. 38, pp. 529-535, 2008.

https://doi.org/10.1007/s00170-007-1079-8

[15] S. Anton, S. Andreas, B. Friedrich, 2015. Heat dissipation in turning operations by means of internal cooling, Proc. Eng., Vol. 100, pp. 1116-1123. https://doi.org/10.1016/j.proeng.2015.01.474

[16] M. Sarikaya, A. Güllü, 2014. Taguchi design and response surface methodology based analysis of machining parameters in CNC turning under MQL," Journal of Cleaner Production, Vol. 65, pp. 604-616.

https://doi.org/10.1016/j.jclepro.2013.08.040

[17] Y. Kaynak, T. Lu, I.S. Jawahir, 2014. Cryogenic machininginduced surface integrity: a review and comparison with dry, MQL, and flood-cooled machining, Mach. Sci. Technol., Vol. 18 , pp. 149-198.

https://doi.org/10.1080/10910344.2014.897836

[18] M. Bhuiyan, I. Choudhury, and M. Dahari, 2014. Monitoring the tool wear, surface roughness and chip formation occurrences using multiple sensors in turning, Journal of Manufacturing System, Vol. 33, pp. 476-487. https://doi.org/10.1016/j.jmsy.2014.04.005

[19] CJ. Rao, D. Sreeamulua Arun, and Tom Mathew, 2014 Analysis of tool life during turning operation by determining optimal process parameters, Procedia Engineering, Vol. 97 pp. 241-250. https://doi.org/10.1016/j.proeng.2014.12.247

[20] Mikell P. Groover, 2013. Fundamental of modern manufacturibng; material, processes, and systems, fifth edition, pp.

606.

https://library.villanova.edu/Casa/Record/1858997

[21] Kagade VR and Deshmukh RR, 2011. Experimental investigation of turning operation using carbide inserts, International Journal of Applied Research; Mechanical Engineering, Vol. 1, Issue 1, pp. 87-90. https://www.interscience.in/ijarme/vol1/iss2/4 https://doi.org/10.47893/IJARME.2011.1017

[22] Isik, Y, 2010. An experimental investigation on effect of cutting fluids in turning with coated carbides tool, Journal of Mechanical Engineering, Vol. 56, pp. 3-10. https://www.researchgate.net/publication/267964128

[23] Y. Isik, 2010. An experimental investigation on effect of cutting fluids in turning with coated carbides tool, Journal of Mechanical Engineering, Vol. 56, pp. 195-201. 23. https://www.researchgate.net/publication/267964128

[24] VS. Sharma, M. Dogra, N. Suri, 2009. Cooling techniques for improved productivity in turning," International Journal of Machine Tools and Manufacturing, Vol. 49, pp. 435-453. https://doi.org/10.1016/j.ijmachtools.2008.12.010

[25] S. Palanisamy, S.D. McDonald, M.S. Dargusch, 2009 Effects of coolant pressure on chip formation while turning Ti6Al4V alloy, International Journal of Machine Tools and Manufacturing, Vol. 49, pp. 739-743. https://doi.org/10.1016/j.ijmachtools.2009.02.010

[26] NI. Galanis, DE. Manolakos, NM. Vaxevanidis, 2008. Comparison between dry and wet machining of stainless steel, ICMEN, Vol. 3, pp. 91-98. https://www.researchgate.net/publication/251870152

[27] A. Aggarwal, H. Singh, P. Kumar, and M. Singh, 2008 Optimization of multiple quality characteristics for CNC turning under cryogenic cutting environment using desirability 
function, Journal of Materials Processing Technology, Vol. 205, pp. 42-50.

https://doi.org/10.1016/j.jmatprotec.2007.11.105

[28] D. Adler, WS. Hii, D. Michalek, and J. Sutherland, 2006. Examining the role of cutting fluids in machining and efforts to address associated environmental/health concerns, Mach. Sci. Technol. Vol. 10, pp. 23-58.

https://doi.org/10.1080/10910340500534282

[29] D. O'sullivan and M. Cotterell, 2001. Temperature measurement in single point turning, Journal of Material Processing Technology, Vol. 118, pp. 301-308. https://doi.org/10.1016/S0924-0136(01)00853-6

[30] Weinert KII, Sutherland JW, Wakabayashi T. 2004. Dry machining and minimum quantity lubrication, CIRP Annals,
Vol. 53, Issue 2, pp. 511-537. https://doi.org/10.1016/S0007-8506(07)60027-4

[31] P. Sreejith, B. Ngoi, 2000. Dry machining: machining of the future, Journal of Material Processing Technology. Vol. 101, pp. 287-291.

https://doi.org/10.1016/S0924-0136(00)00445-3

[32] Tugrul Ozel, Yigit Karpat, Luýs Figueira and Paulo Davim J, 2007. Modelling of Surface Finish and Tool Flank Wear in Turning of AISI D2 Steel with Ceramic Wiper Inserts, Material Processing Technology, Vol. 189, pp. 192-198. https://doi.org/10.1016/.j.jmatprotec.2007.01.021

Received on 18-07-2021

Accepted on 01-09-2021

Published on 10-09-2021

DOI: https://doi.org/10.31875/2409-9848.2021.08.2

(C) 2021 Bedada et al.; Zeal Press.

This is an open access article licensed under the terms of the Creative Commons Attribution Non-Commercial License (http://creativecommons.org/licenses/by-nc/3.0/), which permits unrestricted, non-commercial use, distribution and reproduction in any medium, provided the work is properly cited. 